\title{
Analisis Efek Panjang Gelombang Cahaya Terhadap Karakteristik Arus-Tegangan Sel Surya Menggunakan Simulasi Berbasis Finite Element Method
}

\author{
Fitriana ${ }^{l}$ \\ ${ }^{1}$ Teknik Elektro, Fakultas Teknik, Universitas Muhammadiyah Jember
}

fitrifisika10@gmail.com

\begin{abstract}
Sunlight is one of the factors that play an important role in the formation of electric current in solar cells. Sunlight is composed from photons with various wavelengths, if the sunlight impact the the solar cell surface, it will be converted into electrical energy by the solar cells. The purpose of this study is simulate the distribution profile of charge carrier concentration and the current-voltage (I-V) characteristics of the diode silicon-based solar cells for some photon's wavelengths that received by the solar cell. The simulation result of charge carrier distribution profile and graphs of current-voltage characteristics are obtained by solving the Poisson and continuity equation using the finite element method. The simulation results show that the changes of the photon's wavelenght from $0.5 \mu \mathrm{m}-1.1 \mu \mathrm{m}$ will change the value of the charge carrier concentration and the characteristics of solar cells. That was known from when the wavelength of the photons getting smaller, the value charge carrier concentration and the current density of short circuit will be increasen.
\end{abstract}

Keyword - Photons, I-V characteristics, wavelength, solar cells.

Abstrak - Cahaya matahari merupakan salah satu faktor yang berperan penting dalam pembentukan arus listrik pada sel surya. Cahaya matahari terdiri atas foton-foton dengan berbagai macam panjang gelombang yang jika menumbuk permukaan sel surya akan dikonversi menjadi energi listrik oleh sel surya tersebut. Tujuan dari penelitian ini adalah membuat simulasi profil distribusi konsentrasi pembawa muatan dan karakteristik arus-tegangan (I-V) dari sel surya berbasis silikon untuk berbagai variasi panjang gelombang foton datang yang diterima oleh sel surya. Hasil simulasi profil distribusi pembawa muatan dan grafik karakteristik arus-tegangan diperoleh dengan menyelesaikan persamaan Poisson dan kontinuitas dengan menggunakan metode elemen hingga. Hasil simulasi menunjukkan bahwa perubahan panjang gelombang foton datang dari $0.5 \mu \mathrm{m}-1.1 \mu \mathrm{m}$ akan merubah nilai konsentrasi pembawa muatan dan karakteristik arus-tegangan sel surya. Hal ini ditunjukkan dengan adanya penurunan konsentrasi hole dan elektron dan rapat arus hubung singkat saat panjang gelombang cahaya semakin kecil..

Kata kunci - Foton, karakteristik I-V, panjang gelombang, sel surya..

\section{PENDAHULUAN}

Sel surya merupakan salah satu sumber energi terbarukan yang mengkonversi secara langsung energi matahari menjadi energi listrik. Jumlah energi matahari yang banyak dan cenderung melimpah di Indonesia yaitu sekitar 4,8 $\mathrm{kWh} / \mathrm{m}^{2} /$ hari menyebabkan sel surya berpotensi untuk memenuhi kebutuhan energi Indonesia di masa sekarang dan masa yang akan datang [1]. Potensi penggunaan energi matahari sebagai sumber energi terbarukan ini membuat divais sel surya perlu untuk terus dikembangkan. Usaha pengembangan divais sel surya yang perlu dilakukan adalah cara untuk memperoleh sel surya yang memiliki efisiensi yang tinggi, murah dan mudah dalam kegiatan produksi.

Divais sel surya dapat berupa dioda (persambungan $\mathrm{p}-\mathrm{n}$ ) yang terdiri atas semikonduktor tipe-n dan semikonduktor tipe-p. Saat cahaya matahari mengenai sel surya, maka cahaya tersebut akan diserap atau dipantulkan. Energi dari cahaya yang diserap inilah yang dapat melepaskan elektron dari ikatan atomnya sehingga elektron akan terlepas dan menjadi elektron bebas sehingga timbul arus listrik. Suatu bahan semikonduktor diharapkan dapat menyerap seluruh radiasi sinar matahari agar efisiensinya semakin besar. Agar sel surya dapat menyerap sinar matahari yang bermacammacam panjang gelombangnya maka sel surya harus terbuat dari bahan yang memiliki bandgap dengan range yang lebar [2].

Parameter yang perlu dikaji pada penelitian mengenai sel surya adalah pengaruh sifat fisis cahaya matahari terhadap keluaran sel surya. Hal ini dikarenakan cahaya matahari merupakan sumber energi agar terbentuk arus pada suatu sel surya.Berdasarkan hasil simulasi pengaruh panjang gelombang foton datang terhadap laju generasi sel surya berbasis $\mathrm{SiGe}$ (silikon-germanium) yang dilakukan oleh Rahayu [3], peningkatan panjang gelombang foton datang dari (400-800) nm akan meningkatkan laju generasi sel surya dan laju generasi menurun ketika panjang gelombangnya lebih dari $800 \mathrm{~nm}$. Namun, pada penelitiannya tersebut belum ada kajian bagaimana pengaruh panjang gelombang gelombang foton tersebut terhadap kinerja sel surya.

Pada penelitian ini, akan dilakukan simulasi karaktersitik arus-tegangan (I-V) sel surya silikon dengan memvariasikan panjang gelombang cahaya yang diterima oleh sel surya tersebut dengan menggunakan metode elemen hingga (finite element method). Pertimbangan penggunaan metode elemen hingga (MEH) pada penelitian ini adalah $\mathrm{MEH}$ dapat dengan mudah menyelesaikan persamaan matematis yang mengandung diferensial parsial yang banyak ditemukan 
pada persamaan sel surya. Geometri sel surya dan metode elemen hingga yang digunakan pada penelitian kali ini merujuk pada kegiatan simulasi yang dilakukan oleh Daniellson [4]. Geometri dan metode yang serupa juga pernah dilakukan oleh Kurniawan untuk meneliti pengaruh temperatur operasional terhadap karakteristik arus-tegangan dioda Si melalui suatu kegiatan simulasi [5]. Kegiatan simulasi yang dilakukan oleh Daniellson dan Kurniawan tersebut tidak memperhitungkan rapat fluks foton sedangkan pada penelitian ini rapat fluks foton akan diperhitungkan.

\section{STUDI PUSTAKA}

Cahaya terdiri atas partikel-partikel kecil yang disebut foton dan foton ini mempunyai sifat materi dan gelombang. Banyaknya foton yang menumbuk permukaan depan sel surya per $\mathrm{cm}^{2}$ per detik disebut dengan rapat fluks foton $(F)$ [6]. Rapat fluks foton yang diterima sel surya bergantung pada panjang gelombang fotonnya $(\lambda)$ dan ditentukan dengan persamaan (1) dan (2) berikut:

Untuk panjang gelombang $0,24 \mu \mathrm{m} \leq \lambda \leq 0,4 \mu \mathrm{m}$

$$
F=C(19,7 \lambda-4,7) x 10^{15} \mathrm{~cm}^{-2} \mathrm{~s}^{-1}
$$

Untuk panjang gelombang $\lambda \geq 0,48 \mu \mathrm{m}$

$$
F=C(-2,5 \lambda+5,7) \times 10^{15} \mathrm{~cm}^{-2} \mathrm{~s}^{-1}
$$

$C$ merupakan koefisien konsentrasi fluks sinar matahari. Nilai $C=1$ saat kondisi 1 sun [7]. Kondisi 1 sun adalah kondisi saat daya radiasi matahari yang diterima permukaan bumi sebesar $1000 \mathrm{~W} / \mathrm{m}^{2}$ [8].

Sinar matahari yang mengenai permukaan sel surya yang berupa dioda sambungan $\mathrm{p}-\mathrm{n}$ akan membangkitkan pasangan elektron-hole. Pasangan elektron-hole ini terbentuk akibat eksitasi elektron dari pita valensi ke pita konduksi sehingga pada pita valensi akan terbentuk hole. Laju pembangkitan elektron-hole ini disebut dengan laju generasi yang dapat ditentukan dengan persamaan (3) berikut :

$$
G=\frac{F \alpha}{1-P}\left(e^{-\alpha y}+P e^{\alpha y}\right)
$$

dimana $G$ merupakan laju generasi $\left(\mathrm{cm}^{-3} \mathrm{~s}^{-1}\right), F$ merupakan rapat fluks foton $\left(\mathrm{cm}^{-2} \mathrm{~s}^{-1}\right), P$ merupakan koefisien transmisi cahaya, $\alpha$ merupakan koefisien absorpsi $\left(\mathrm{cm}^{-1}\right)$ dan $y$ merupakan posisi dalam sel surya yang ditentukan dari tepi teratas tipe-p (cm) [9].

Saat elektron pada pita valensi kehilangan energinya, elektron pada pita konduksi akan bergerak ke pita valensi sehingga menghilangkan hole pada pita valensi dan elektron pada pita konduksi. Proses penghilangan pasangan elektronhole ini disebut dengan rekombinasi. Laju rekombinasi $(R)$ bergantung pada jumlah pembawa muatan pada bahan semikonduktor. Pada bahan sel surya yang terbuat dari semikonduktor dengan transisi tidak langsung (indirect transition) seperti: Silikon (Si) dan Germanium (Ge), laju rekombinasinya dapat ditentukan dengan Shockley Read Hall Recombination $(R)$ yang dinyatakan dalam persmaan (4) berikut:

$$
R=\frac{p n-n_{i}^{2}}{\tau_{p}\left(p+p_{1}\right)+\tau_{n}\left(n+n_{1}\right)}
$$

Keterangan:

$p=$ konsentrasi hole $\left(\mathrm{cm}^{-3}\right)$

$n=$ konsentrasi elektron $\left(\mathrm{cm}^{-3}\right)$

$n_{i}=$ konsentrasi intrinsik $\left(\mathrm{cm}^{-3}\right)$

$\tau_{p}=$ waktu hidup rekombinasi hole $(\mu \mathrm{s})$

$\tau_{n}=$ waktu hidup rekombinasi elektron $(\mu \mathrm{s})$

$R=$ laju rekombinasi $\left(\mathrm{cm}^{-3} / \mathrm{s}\right)$

$n_{1}=$ konsentrasi elektron yang bergantung pada lokasi tingkat trap pada celah pita energi $\left(\mathrm{cm}^{-3}\right)$

$p_{1}=$ konsentrasi hole yang bergantung pada lokasi tingkat trap pada celah pita energi $\left(\mathrm{cm}^{-3}\right)$ [10]

Sifat kelistrikan dari sel surya dapat diamati melalui karakteristik arus-tegangannya dalam bentuk grafik $I-V$. Paramater grafik $I-V$ terdiri atas arus hubung singkat $\left(I_{s c}\right)$ yang terjadi pada kondisi tidak ada resistansi ( $V=0$ volt), tegangan hubung terbuka $\left(V_{o c}\right)$ yang dicapai ketika arus pada sel surya sama dengan nol, daya maksimum $\left(P_{\max }\right)$ yang merupakan daya terbesar yang dihasilkan sel surya, dan Fill Factor $(F F)$ yang merupakan perbandingan antara daya maksimum yang dihasilkan sel surya dengan perkalian antara $I_{s c}$ dan $V_{o c}[11]$.

\section{METODE PENELITIAN}

Metode yang digunakan pada penelitian ini adalah finite element method atau metode elemen hingga. Pada simulasi divais semikonduktor yang berupa dioda persambungan $\mathrm{p}-\mathrm{n}$, geometri dioda akan dibagi menjadi elemen segitiga-segitiga kecil. Variabel yang digunakan pada simulasi divais semikonduktor adalah $\Psi$, $\mathrm{p}$, dan n yang secara berturut-turut merupakan potensial elektrostatik, konsentrasi hole, dan konsentrasi elektron. Variabel $\Psi$, p, dan $\mathrm{n}$ berhubungan dengan tingkat quasi-Fermi pembawa muatan yang dituliskan dalam persamaan (5) dan (6) berikut:

$$
\begin{gathered}
n=n_{i} e^{\Psi} u \\
p=p_{i} e^{-\Psi} v
\end{gathered}
$$

Keterangan:

$\mathrm{n}=$ konsentrasi elektron $\left(\mathrm{cm}^{-3}\right)$

$\mathrm{n}_{\mathrm{i}}=$ konsentrasi elektron intrinsik $\left(\mathrm{cm}^{-3}\right)$

$\mathrm{p}=$ konsentrasi hole $\left(\mathrm{cm}^{-3}\right)$

$\mathrm{p}_{\mathrm{i}}=$ konsentrasi hole intrinsik $\left(\mathrm{cm}^{-3}\right)$

Geometri sel surya yang akan disimulasikan pada penelitian ini berbentuk 2 dimensi yang terdiri atas 2 daerah subdomain yaitu subdomain 1 (lapisan-n) dan subdomain 2 (lapisan-p) seperti yang ditunjukkan pada Gambar 1. Pada gambar 1 terlihat bahwa geometri sel surya adalah berupa persambungan $\mathrm{p}-\mathrm{n}$ dalam bentuk 2 dimensi terdiri dari 9 batas. Batas 5 merupakan anoda, batas 2 merupakan katoda sedangkan batas 4 dan 9 merupakan daerah persambungan (junction). 


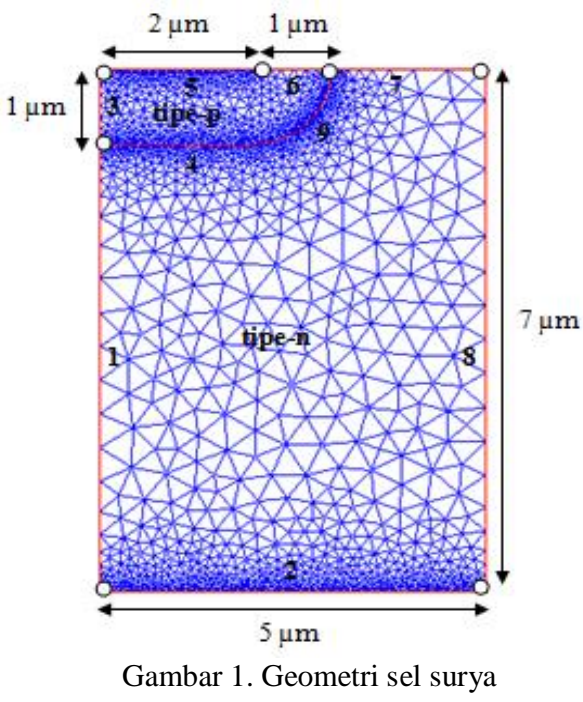

Proses kegiatan simulasi tersebut dari awal sampai akhir dapat dilihat pada pada Gambar 2.

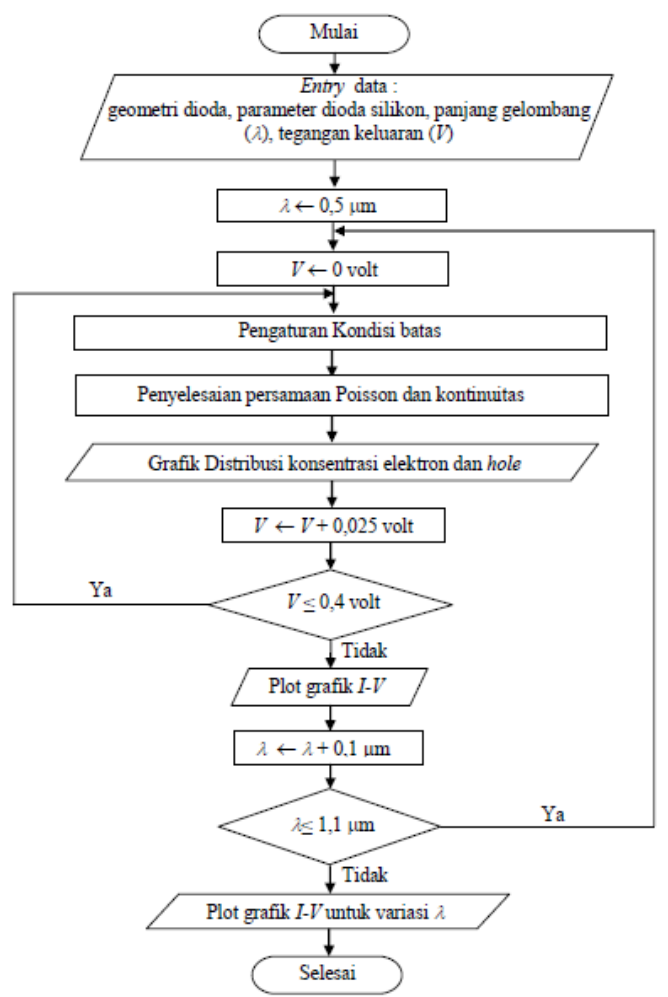

Gambar 2. Diagram alir kegiatan simulasi

Kegiatan simulasi diawali dengan membuat geometri sel surya yang ditunjukkan pada Gambar 1 dan dilanjutkan dengan memasukkan data input yang berupa parameter dioda silikon, data panjang gelombang, dan tegangan keluaran. Parameter input dioda silikon yang berupa konstanta dalam fisika yang digunakan pada penelitian ini adalah besar muatan elektron $(q)$ yang nilainya $\left(1,6 \times 10^{-19}\right)$ $\mathrm{C}$, permisivitas ruang hampa $\left(\varepsilon_{0}\right)$ yang nilainya $\mathrm{F} / \mathrm{m}$ dan konstanta Boltzman $(k)$ yang nilainya $\left(1,381 \times 10^{-23}\right) \mathrm{J} / \mathrm{K}$.
Paramater input lain yang merupakan parameter dioda silikon adalah konstanta difusi elektron $\left(D_{n}\right)$ yang nilainya $20,7 \mathrm{~cm}^{2} / \mathrm{s}$, konstanta difusi hole $\left(D_{p}\right)$ yang nilainya 5,17 $\mathrm{cm}^{2} / \mathrm{s}$ dan permitivitas bahan $\left(\varepsilon_{r}\right)$ yang nilainya 11,8 untuk bahan silikon. Laju rekombinasi yang digunakan pada kegiatan simulasi ini dihitung dengan menggunakan parameter kristal silikon yang berupa life time elektron $\left(\tau_{n}\right)$ dan life time hole $\left(\tau_{p}\right)$ yang secara berturut-turut nilainya adalah $350 \mu$ s dan $1 \mu \mathrm{s}$. Parameter input untuk perhitungan laju generasi terdiri atas koefisien transmisi cahaya $(P)$ yang nilainya 0,023 , koefisien konsentrasi fluks sinar matahari yang nilainya 1 , koefisien absorpsi $(\alpha)$ yang nilainya $(1,1 \mathrm{x}$ $\left.10^{4}\right) / \mathrm{cm}$, dan panjang gelombang foton datang yang divariasi dari $0,5 \mu \mathrm{m}$ sampai $1,1 \mu \mathrm{m}$. Pada penelitian ini, karakteristik $I-V$ dioda sel surya diperoleh dengan memvariasikan tegangan keluaran $(V)$ dari 0 volt sampai 0,4 volt.

Langkah selanjutnya adalah melakukan pengaturan kondisi batas. Daerah 2 dan 5 merupakan daerah batas dioda dengan konduktor sehingga kondisi batas yang digunakan adalah kondisi batas Neumann [12] yang dinyatakan dalam persamaan (7), (8), dan (9) berikut:

$$
\begin{aligned}
& \Psi=V+\frac{k T}{q} \ln \left(\frac{\frac{N}{2}+\sqrt{\left(\frac{N}{2}\right)^{2}+n_{i}^{2}}}{n_{i}}\right) \\
& p=-\frac{N}{2}+\sqrt{\left(\frac{N}{2}\right)^{2}+n_{i}^{2}}
\end{aligned}
$$

$\Psi=$ Besaran $N$ pada persamaan (7), (8), dan (9) merupakan fungsi konsentrasi dopan yang dituliskan dalam persamaan (10) berikut:

$$
\begin{aligned}
N= & N D_{n}+N D_{n \max } e^{-\left(\frac{y+y_{1}}{c h}\right)^{2}}-N A_{p \max } e^{-\left(\frac{y}{c h}\right)^{2}}((x<a c)+ \\
& \left.(x \geq a c) e^{-\left(\frac{x-a c}{c h}\right)^{2}}\right)
\end{aligned}
$$

Besaran ch pada persamaan (10) ditentukan dengan menggunakan persamaan:

$$
c h=\frac{j u}{\sqrt{\log \left(N A_{p \max } / N D_{n}\right)}}
$$

Keterangan:

$N D_{n} \quad=$ konsentrasi donor pada daerah tipe- $\mathrm{n}$

$$
=\left(1 \times 10^{15}\right) \mathrm{cm}^{-2}
$$

$N D_{\text {max }}=$ konsentrasi donor maksimum (tertinggi) pada daerah tipe-n

$=\left(1 \times 10^{17}\right) \mathrm{cm}^{-2}$

$N D_{\text {pmax }}=$ konsentrasi akseptor tertinggi pada daerah tipe-p

$$
=\left(1 \times 10^{17}\right) \mathrm{cm}^{-2}
$$

$a c=$ panjang batas 5 pada geometri dioda $=2 \mu \mathrm{m}$

$j u=$ panjang batas 6 pada geometri dioda $=1 \mu \mathrm{m}$

$\mathrm{y}_{1}=$ panjang geometri dioda $=7 \mu \mathrm{m}$ 
Daerah batas 1, 3, 4, 6, 7, 8, dan 9 merupakan daerah daerah batas yang tidak berhubungan konduktor sehingga kondisi batas yang digunakan adalah kondisi batas Dirichlet pada persamaan (12), (13), dan (14) berikut ini :

$$
\begin{aligned}
& \hat{n} \cdot \vec{E}=0 \\
& \hat{n} \cdot \vec{J}_{n}=0 \\
& \hat{n} \cdot \vec{J}_{p}=0
\end{aligned}
$$

Hal yang dilakukan berikutnya adalah menyelesaikan persamaan poisson dan kontinuitas. Persamaan poisson dengan konsentrasi dopan $N$ dapat ditentukan dengan menggunakan rumus:

$$
\Delta \Psi=\frac{q}{\varepsilon}\left(e^{\Psi} u-e^{-\Psi} v-N\right)
$$

sedangkan persamaan kontinuitas ditentukan dengan rumus:

$$
\begin{aligned}
& \frac{1}{q} \vec{\nabla} \cdot \vec{J}_{n}=R-G \\
& \frac{1}{q} \vec{\nabla} \cdot \vec{J}_{p}=G-R
\end{aligned}
$$

dimana $J_{n}$ menyatakan rapat arus elektron, $J_{p}$ menyatakan rapat arus hole, $G$ menyatakan laju generasi yang ditentukan mengunakan persamaan (3), dan $R$ menyatakan laju rekombinasi yang ditentukan dengan menggunakan persamaan (4). Penyelesaian persamaan Poisson dan persamaan kontinuitas akan menghasilkan distribusi konsentrasi hole dan elektron pada dioda sel surya yang digunakan untuk menghitung rapat arus hole dan rapat arus elektron pada dioda sel surya. Persamaan yang digunakan untuk menentukan rapat arus elektron dan arus hole secara berturut-turut adalah sebagai berikut:

$$
\begin{gathered}
\vec{J}_{n}=q D_{n} n_{i} e^{\Psi} \vec{\nabla} u \\
\vec{J}_{p}=-q D_{n} n_{i} e^{-\Psi} \vec{\nabla} v
\end{gathered}
$$

Rapat arus yang digunakan untuk menentukan karakteristik $I$ - $V$ dioda sel surya adalah rapat arus total $(J)$ yang ditentukan dengan mengunakan persamaan:

$$
\vec{J}=\vec{J}_{n}+\vec{J}_{p}
$$

Disamping itu, pengaruh panjang gelombang foton datang terhadap profil distribusi pembawa muatan dan karakteristik $I-V$ dioda sel surya dianalisis dengan menentukan pengaruh panjang gelombang foton datang terhadap laju generasi dari sel surya. Titik pengamatan yang digunakan untuk mengamati profil distribusi pembawa muatan dan pembuatan grafik pengaruh panjang gelombang foton datang terhadap laju generasi pembawa muatan sel surya adalah titik dekat anoda, titik persambungan (junction) dan titik dekat katoda.

\section{HASIL DAN PEMBAHASAN}

\section{A. Pengaruh Panjang Gelombang Cahaya terhadap Laju Generasi}

Pada penelitian ini, dihasilkan grafik pengaruh panjang gelombang cahaya yang diterima sel surya terhadap laju generasi untuk beberapa titik pengamatan yang ditampilkan pada Gambar 2. Hasil simulasi ini digunakan untuk menganalisis profil distribusi konsentrasi pembawa muatan dan karakteristik arus-tegangan dari sel surya. Titik pengamatan yang digunakan adalah titik dekat anoda, titik persambungan (junction) dan titik dekat katoda. Hasil simulasi yang ditampilkan pada Gbr.3 menunjukkan bahwa meningkatnya panjang gelombang foton datang akan menurunkan laju generasi pembawa muatan pada sel surya. Hal ini dikarenakan panjang gelombang foton datang yang besar akan menurunkan energi yang diterima oleh sel surya untuk melepaskan elektron dari ikatan kovalennya sehingga hanya sedikit elektron dan hole yang terbentuk yang artinya laju generasi sel surya tersebut kecil. Gbr.3 juga menunjukkan bahwa semakin jauh dari anoda, laju generasi dalam dioda sel surya akan semakin menurun. Penurunan laju generasi ini dikarenakan semakin jauh dari anoda, energi matahari yang diterima pada daerah tersebut semakin berkurang yang menyebabkan elektron dan hole yang terlepas dari ikatan kovalennya semakin menurun yang menyebabkan penurunan laju generasi.

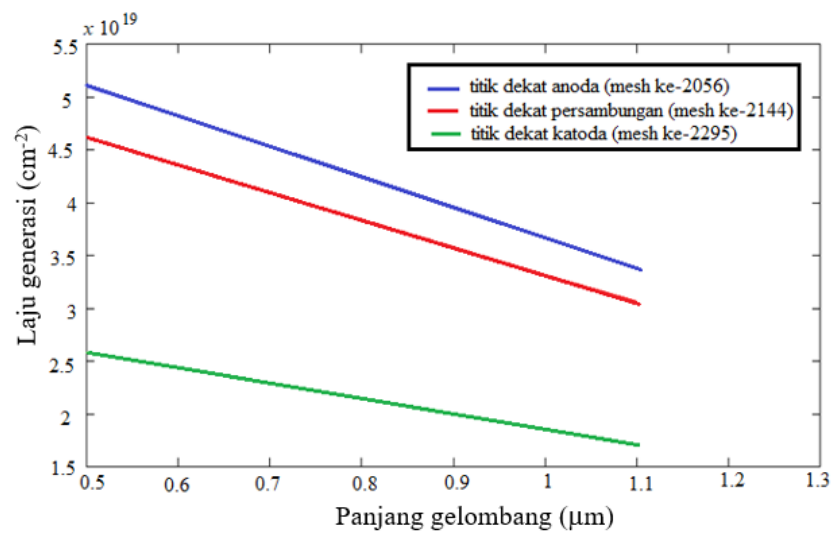

Gambar 3. Hasil simulasi pengaruh panjang gelombang foton datang $(\lambda)$ terhadap laju generasi sel surya.

\section{B. Profil Distribusi Konsentrasi Elektron dan Hole}

Hasil simulasi profil distribusi konsentrasi elektron pada penelitian ini dapat dilihat pada Gambar 4. Berdasarkan Gambar 4 tersebut diketahui bahwa konsentrasi elektron terendah berada pada ujung daerah tipe-n. Konsentrasi elektron pada daerah tersebut semakin meningkat hingga daerah tipe-p dekat persambungan (junction), lalu turun kembali di daerah tipe-p dekat persambungan. Pada daerah tipe-p dekat persambungan, konsentrasi elektron mengalami peningkatan sampai daerah tipe-n dekat katoda.

Hasil simulasi profil distribusi konsentrasi hole pada penelitian ini dapat dilihat pada Gambar 5. Berdasarkan hasil simulasi pada Gambar 5 diketahui bahwa konsentrasi hole tertinggi berada pada daerah tipe-p dekat anoda. Konsentrasi hole pada daerah di dekat anoda terus menurun sampai tipe-n dekat daerah persambungan. Konsentrasi hole tersebut kemudian meningkat kembali pada daerah pertengahan tipe-n. Pada pertengahan daerah tipe-n sampai daerah tipe-n dekat katoda, konsentrasi hole kembali 
mengalami penurunan hingga mencapai konsentrasi hole terendah yang berada pada daerah tipe-n dekat katoda.

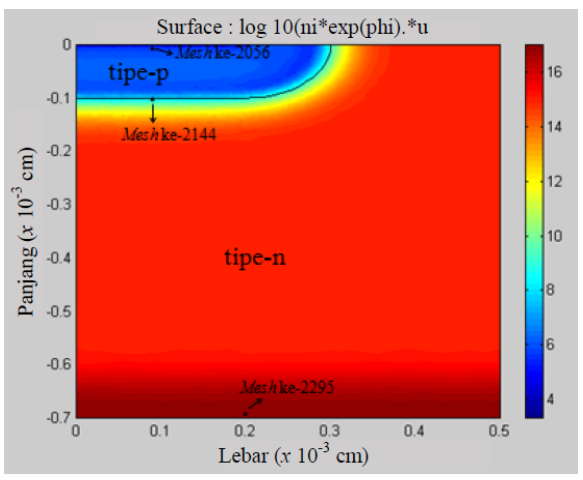

Gambar 4. Hasil simulasi profil distribusi konsentrasi elektron untuk panjang gelombang foton datang $(\lambda) 0,5 \mu \mathrm{m}$ dan tegangan keluaran $(V) 0$ volt

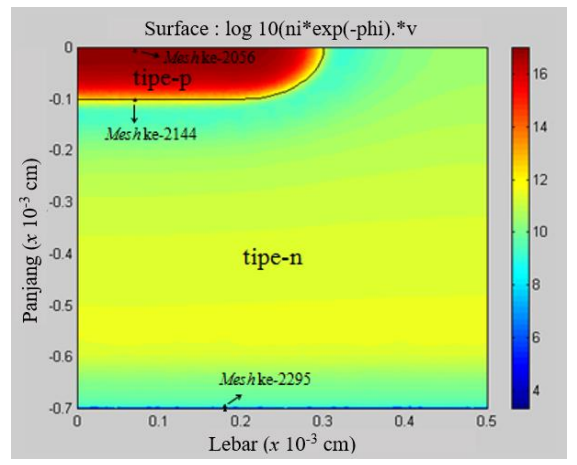

Gambar 5. Hasil simulasi profil distribusi konsentrasi hole untuk panjang gelombang foton datang $(\lambda) 0,5 \mu \mathrm{m}$ dan tegangan keluaran (V) 0 volt.

\section{Konsentrasi Elektron dan Hole Pada Berbagai Variasi Panjang Gelombang Cahaya}

Pada penelitian ini dilakukan pemvariasian panjang gelombang foton datang yang mengenai sel surya dari $0,5 \mu \mathrm{m}$ sampai $1,1 \mu \mathrm{m}$. Nilai konsentrasi elektron dan hole pada berbagai variasi panjang gelombang tersebut untuk $V=0$ volt dapat dilihat pada Tabel I dan tabel II.

TABEL I

KONSENTRASI ELEKTRON PADA V $=0$ VOLT

\begin{tabular}{|c|c|c|c|}
\hline \multirow{2}{*}{$\begin{array}{c}\text { Panjang } \\
\text { Gelombang }\end{array}$} & \multicolumn{3}{|c|}{ Konsentrasi Elektron $\left(\mathbf{c m}^{-2}\right)$} \\
\cline { 2 - 4 } & Dekat Anoda & Persambungan & Dekat Katoda \\
\cline { 2 - 4 } & $(\boldsymbol{m e s h}$ ke-2056) & $($ mesh ke-2144) & $($ mesh ke-2295) \\
\hline$\lambda=0,5 \mu \mathrm{m}$ & $2,35483 \times 10^{5}$ & $1,34076 \times 10^{8}$ & $1,00554 \times 10^{17}$ \\
\hline$\lambda=0,6 \mu \mathrm{m}$ & $1,80256 \times 10^{5}$ & $1,25262 \times 10^{8}$ & $1,00462 \times 10^{17}$ \\
\hline$\lambda=0,7 \mu \mathrm{m}$ & $1,58391 \times 10^{5}$ & $1,12863 \times 10^{8}$ & $1,00323 \times 10^{17}$ \\
\hline$\lambda=0,8 \mu \mathrm{m}$ & $1,31417 \times 10^{5}$ & $1,03507 \times 10^{8}$ & $1,00184 \times 10^{17}$ \\
\hline$\lambda=0,9 \mu \mathrm{m}$ & $1,07228 \times 10^{5}$ & $0,95466 \times 10^{8}$ & $1,00023 \times 10^{17}$ \\
\hline$\lambda=1,0 \mu \mathrm{m}$ & $0,94611 \times 10^{5}$ & $0,79781 \times 10^{8}$ & $0,99930 \times 10^{17}$ \\
\hline$\lambda=1,1 \mu \mathrm{m}$ & $0,86403 \times 10^{5}$ & $0,73142 \times 10^{8}$ & $0,99861 \times 10^{17}$ \\
\hline
\end{tabular}

TABEL II

KONSENTRASI HOLE PADA V $=0$ VOLT

\begin{tabular}{|c|c|c|c|}
\hline \multirow{2}{*}{$\begin{array}{c}\text { Panjang } \\
\text { Gelombang }\end{array}$} & \multicolumn{3}{|c|}{ Konsentrasi Hole $\left(\mathbf{c m}^{-2}\right)$} \\
\cline { 2 - 4 } & Dekat Anoda & Persambungan & Dekat Katoda \\
\cline { 2 - 4 } & $($ mesh ke-2056) & $($ mesh ke-2144) & $($ mesh ke-2295) \\
\hline$\lambda=0,5 \mu \mathrm{m}$ & $9,86052 \times 10^{16}$ & $1,99022 \times 10^{12}$ & $1,45908 \times 10^{9}$ \\
\hline$\lambda=0,6 \mu \mathrm{m}$ & $9,85372 \times 10^{16}$ & $1,81009 \times 10^{12}$ & $1,37727 \times 10^{9}$ \\
\hline$\lambda=0,7 \mu \mathrm{m}$ & $9,84464 \times 10^{16}$ & $1,69981 \times 10^{12}$ & $1,29405 \times 10^{9}$ \\
\hline$\lambda=0,8 \mu \mathrm{m}$ & $9,83558 \times 10^{16}$ & $1,55991 \times 10^{12}$ & $1,23914 \times 10^{9}$ \\
\hline$\lambda=0,9 \mu \mathrm{m}$ & $9,82653 \times 10^{16}$ & $1,47231 \times 10^{12}$ & $1,18269 \times 10^{9}$ \\
\hline$\lambda=1,0 \mu \mathrm{m}$ & $9,81974 \times 10^{16}$ & $1,32190 \times 10^{12}$ & $1,14462 \times 10^{9}$ \\
\hline$\lambda=1,1 \mu \mathrm{m}$ & $9,81070 \times 10^{16}$ & $1,31129 \times 10^{12}$ & $1,07285 \times 10^{9}$ \\
\hline
\end{tabular}

Hasil simulasi yang ditampilkan pada Tabel I dan Tabel II menunjukkan adanya penurunan konsentrasi hole dan elektron ketika panjang gelombang foton datang meningkat. Hal ini dikarenakan menurunnya laju generasi pembawa muatan pada sel surya ketika panjang gelombang foton datang semakin meningkat.

Pengaruh panjang gelombang terhadap konsentrasi elektron dan hole pada variasi tegangan keluaran $(V)$ untuk posisi dekat katoda dapat dilihat pada Tabel III dan Tabel IV. Berdasarkan Tabel III dan Tabel IV tersebut dapat diketahui bahwa untuk tegangan keluaran yang berbedabeda pengaruh panjang gelombang terhadap konsentrasi pembawa muatan (elektron dan hole) adalah sama yaitu meningkatnya panjang gelombang foton datang yang mengenai sel surya akan menurunkan konsentrasi pembawa muatan pada divais sel surya tersebut.

Pengaruh panjang gelombang terhadap konsentrasi elektron dan hole pada variasi tegangan keluaran $(V)$ untuk posisi dekat katoda dapat dilihat pada Tabel III dan Tabel IV. Berdasarkan Tabel III dan Tabel IV tersebut dapat diketahui bahwa untuk tegangan keluaran yang berbedabeda pengaruh panjang gelombang terhadap konsentrasi pembawa muatan (elektron dan hole) adalah sama yaitu meningkatnya panjang gelombang foton datang yang mengenai sel surya akan menurunkan konsentrasi pembawa muatan pada divais sel surya tersebut.

TABEL III

KONSENTRASI HOLE UNTUK BERBAGAI VARIASI PANJANG GELOMBANG DAN TEGANGAN PADA POSISI DI DEKAT KATODA (MESH KE-2295)

\begin{tabular}{|c|c|c|c|c|c|}
\hline \multirow{2}{*}{$\begin{array}{c}\text { Panjang } \\
\text { Gelombang }\end{array}$} & \multicolumn{5}{|c|}{ Konsentrasi Hole $\left(\mathbf{x ~ 1 0}^{\mathbf{7}} \mathbf{~ c m}^{-2}\right.$ ) } \\
\cline { 2 - 6 }$\lambda=0,5 \mu \mathrm{m}$ & 145,9083 & 123,9596 & 49,4698 & 15,3610 & 4,7767 \\
\hline$\lambda=0,6 \mu \mathrm{m}$ & 137,7273 & 114,3089 & 47,7057 & 13,9656 & 4,2530 \\
\hline$\lambda=0,7 \mu \mathrm{m}$ & 129,4047 & 107,8301 & 45,2752 & 12,6651 & 3,8543 \\
\hline$\lambda=0,8 \mu \mathrm{m}$ & 123,9139 & 104,0687 & 42,7376 & 12,0534 & 3,6341 \\
\hline$\lambda=0,9 \mu \mathrm{m}$ & 118,2687 & 102,4495 & 40,4706 & 11,8301 & 3,4842 \\
\hline$\lambda=1,0 \mu \mathrm{m}$ & 114,4616 & 94,0329 & 37,5077 & 11,3907 & 3,4058 \\
\hline$\lambda=1,1 \mu \mathrm{m}$ & 107,2852 & 92,0365 & 35,4969 & 10,5604 & 3,2013 \\
\hline
\end{tabular}


TABEL $1 \mathrm{~V}$

KONSENTRASI ELEKTRON UNTUK BERBAGAI VARIASI PANJANG GELOMBANG DAN TEGANGAN PADA POSISI DI DEKAT KATODA (MESH KE-2295)

\begin{tabular}{|c|c|c|c|c|c|}
\hline \multirow{2}{*}{$\begin{array}{c}\text { Panjang } \\
\text { Gelombang }\end{array}$} & \multicolumn{5}{|c|}{ Konsentrasi Elektron $\left(\mathbf{x ~ 1 0}^{\mathbf{1 6}} \mathbf{c m}^{-2}\right)$} \\
\cline { 2 - 6 } & $\mathbf{0}$ volt & $\mathbf{0 , 1}$ volt & $\mathbf{0 , 2}$ volt & $\mathbf{0 , 3}$ volt & $\mathbf{0 , 4}$ volt \\
\hline$\lambda=0,5 \mu \mathrm{m}$ & 10,0554 & 10,0184 & 9,9678 & 9,8492 & 9,6339 \\
\hline$\lambda=0,6 \mu \mathrm{m}$ & 10,0462 & 10,0046 & 9,9197 & 9,8175 & 9,5148 \\
\hline$\lambda=0,7 \mu \mathrm{m}$ & 10,0323 & 9,9839 & 9,9038 & 9,7994 & 8,9826 \\
\hline$\lambda=0,8 \mu \mathrm{m}$ & 10,0184 & 9,9770 & 9,5082 & 9,7904 & 8,8920 \\
\hline$\lambda=0,9 \mu \mathrm{m}$ & 10,0023 & 9,9724 & 9,2109 & 9,5302 & 8,5271 \\
\hline$\lambda=1,0 \mu \mathrm{m}$ & 9,9931 & 9,9655 & 9,0178 & 8,8328 & 8,3483 \\
\hline$\lambda=1,1 \mu \mathrm{m}$ & 9,9862 & 9,9586 & 8,8777 & 8,6596 & 8,0408 \\
\hline
\end{tabular}

\section{Karakteristik I-V (Arus-Tegangan)}

Hasil simulasi konsentrasi elektron dan hole yang diperoleh kemudian digunakan untuk menentukan karakteristik arus-tegangan dengan memvariasikan tegangan output (keluaran). Pemvariasian tegangan output(keluaran) dari 0 volt sampai 0,4 volt. Pengaruh panjang gelombang cahaya $(\lambda)$ terhadap karakteristik arus-tegangan sel surya dapat diketahui melalui arus dan tegangan keluarannya. Hasil simulasi karakteristik arus-tegangan sel surya pada berbagai variasi panjang gelombang ditunjukkan pada Gbr. 7 berikut:

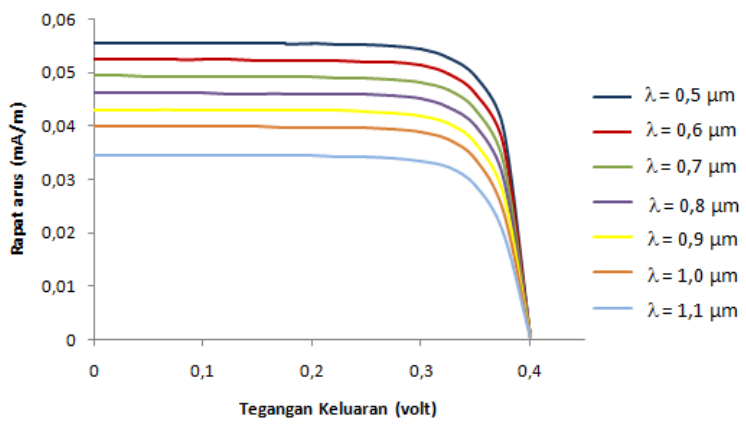

Gambar 6. Hasil simulasi karakteristik $I-V$ sel surya untuk beberapa panjang gelombang

Gambar 6 menunjukkan adanya penurunan $J_{s c}$ (Rapat arus hubung singkat) ketika panjang gelombang foton datang yang mengenai sel surya semakin besar. Hal ini dapat disebabkan karena menurunnya laju generasi sel surya ketika panjang gelombang foton datang semakin besar seperti yang diperlihatkan pada Gambar 3. Peningkatan panjang gelombang foton datang membuat energi yang diterima oleh sel surya semakin mengecil. Energi yang kecil ini menyebabkan mengecilnya laju generasi sehingga hanya sedikit pasangan elektron-hole yang terbentuk. Pasangan elektron-hole ini kemudian akan mengalir menjadi arus listrik sehingga semakin kecil pasangan elektron-hole yang terbentuk maka arus yang terbentuk juga semakin mengecil. Hal inilah yang menyebabkan peningkatan panjang gelombang akan menurunkan rapat arus yang dihasilkan oleh sel surya.

\section{KESIMPULAN}

Berdasarkan hasil simulasi yang didapatkan dan pembahasan yang telah dilakukan maka diperoleh kesimpulan bahwa metode elemen hingga ini berhasil menunjukkan pengaruh panjang gelombang cahaya terhadap karakteristik arus-tegangan suatu sel surya. Hasil simulasi menunjukkan bahwa ketika panjang gelombang cahaya ditingkatkan dari $0,5 \mu \mathrm{m}$ sampai $1,1 \mu \mathrm{m}$, nilai rapat arus hubung singkat $\left(J_{s c}\right)$ tertinggi $(0,0556 \mathrm{~mA} / \mathrm{m})$ didapatkan ketika panjang gelombang cahaya $0,5 \mu \mathrm{m}$ dan terus menurun hingga didapatkan nilai Jsc yang terendah yang didapatkan ketika panjang gelombang foton datang $1,1 \mu \mathrm{m}$. Hal ini menunjukkan bahwa kenaikan panjang gelombang foton datang dari $0,5 \mu \mathrm{m}$ sampai $1,1 \mu \mathrm{m}$ menyebabkan penurunan rapat arus hubung singkat $\left(J_{s c}\right)$.

\section{DAFTAR ACUAN}

[1] Sudarmono, J. Waluto, dan W. Wilopo, "Perancangan Pembangkit Listrik Tenaga Surya (PLTS) Pembasmi Serangga Pada Tanaman Bawang Merah Di Kabupaten Brebes," JATTEC, vol. 1, no. 1, hal. 35-39, Januari 2020.

[2] M. Lolo, Proses Konversi Solar Sel, Makassar: Universitas Hasanudin, 2012

[3] F. Rahayu, Simulasi Sel Surya Pita Tengah Berbasis Titik Kuantum SiGe, Bandung: Institut Teknologi Bandung, 2012.

[4] E. Danielsson, FEMLAB Model Library For Semiconductor Device Model, Stockholom: The Royal Institute Of Institute, 2000.

[5] H. Kurniawan, Analisis Pengaruh Temperatur Operasional dalam Simulasi Karakteristik Arus-Tegangan pada Dioda Si menggunakan FEMLAB, Jember: Universitas Jember, 2013.

[6] J. Liou, "Comparison and Optimization of The Perfomance of Si and GaAs Solar Cells," Sol. Energy Mater. Sol. Cells, vol. 28, hal. 9-28, October 1992.

[7] D. Rusdiana, Simulasi untuk Optimalisasi Unjuk Kerja Divais-Divais Optoelektronik Berbasis Bahan Film Tipis Semikonduktor, Bandung: Universitas Pendidikan Indonesia, 2004.

[8] A. Rahardjo, Optimalisasi Pemanfaatan Sel Surya pada Bangunan Komersial secara Terintegrasi sebagai Bangunan Hemat Energi, Jakarta: Universitas Indonesia, 2008.

[9] I. Usman, Penumbuhan Lapisan Tipis Silikon Amorf Terhidrogenasi Dengan Teknik HWC-VHF-PECVD Dan Aplikasinya Pada Sel Surya, Bandung: Institut Teknologi Bandung, 2006.

[10] A. Seet, Semiconductor Devices Modelling using Numerical Partial Differential Equation Solver-Simulation and Parameter Extraction of the Haynes-Shockley Experiment, Queensland: University of Queensland, 1998.

[11] K. Anjarani, Studi Karakteristik Arus Tegangan (Kurva I-V) pada Sel Tunggal Polikristal Silikon serta Pemodelannya, Jakarta: UNJ, 2012.

[12] A. Goetzberger, Crystaline Silicon Solar Cell, Chichester: John Wiley and Sons Ltd, 1998. 